\title{
Transcriptional Induction of Prostaglandin G/H Synthase-2 by Basic Fibroblast Growth Factor
}

\author{
Hiroshi Kawaguchi, * Carol C. Pilbeam, * Gloria Gronowicz, * Christine Abreu, * Bradley S. Fletcher,” \\ Harvey R. Herschman, ${ }^{\star}$ Lawrence G. Raisz, ${ }^{*}$ and Marja M. Hurley* \\ *Division of Endocrinology and Metabolism, Department of Medicine, University of Connecticut Health Center, Farmington, \\ Connecticut 06030; and ${ }^{\ddagger}$ Department of Biological Chemistry, UCLA School of Medicine, Los Angeles, California 90024
}

\begin{abstract}
In serum-free mouse osteoblastic MC3T3-E1 cells, basic fibroblastic growth factor (bFGF) induced mRNA and protein for prostaglandin G/H synthase-2 (PGHS-2), the major enzyme in arachidonic acid (AA) conversion to prostaglandins. mRNA accumulation peaked at $1 \mathrm{~h}$ with bFGF $1 \mathrm{nM}$. In cells stably transfected with a 371-bp PGHS-2 promoterluciferase reporter, bFGF stimulated luciferase activity, which peaked at 2-3 h with bFGF 1-10 nM. In the presence of exogenous AA, bFGF stimulated $\mathrm{PGE}_{2}$ production, which paralleled luciferase activity. In serum-free neonatal mouse calvarial cultures, bFGF stimulated $\mathrm{PGE}_{2}$ production in the absence of exogenous AA. bFGF stimulated PGHS-2 mRNA accumulation, which peaked at $2-4 \mathrm{~h}$ and then decreased; there were later mRNA elevations at 48 and $96 \mathrm{~h}$ that were inhibited by indomethacin. In both MC3T3-E1 cells and neonatal calvariae, bFGF produced smaller and slower increases in PGHS-1 mRNA levels than for PGHS-2. bFGF stimulated bone resorption in mouse calvariae with a maximal increase of $80 \%$ at $1 \mathrm{nM}$. Stimulation was partially inhibited by nonsteroidal anti-inflammatory drugs. We conclude that bFGF rapidly stimulates $\mathrm{PGE}_{2}$ production in osteoblasts, largely through transcriptional regulation of PGHS-2, and that prostaglandins mediate some of bFGF's effects on bone resorption. (J. Clin. Invest. 1995. 96:923930.) Key words: osteoblasts $•$ bone resorption • prostaglandins $\cdot$ indomethacin $\cdot$ luciferase
\end{abstract}

\section{Introduction}

Basic fibroblast growth factor (bFGF), ${ }^{1}$ a member of the family of heparin-binding growth factors, exerts potent mitogenic activity on a variety of cells of mesodermal and ectodermal origin

Address correspondence to Marja M. Hurley, M.D., Division of Endocrinology and Metabolism, Department of Medicine, University of Connecticut Health Center, Farmington, CT 06030. Phone: 203-679-2129; FAX: 203-679-1258. H. Kawaguchi's present address is Department of Orthopedic Surgery, Faculty of Medicine, Tokyo University, 7-3-1 Hongo, Bunkyo-Ku, Tokyo 113, Japan.

Received for publication 6 February 1995 and accepted in revised form 19 April 1995.

1. Abbreviations used in this paper: APC, aphidicolin; bFGF, basic fibroblast growth factor; FGF, fibroblast growth factor; GAPDH, glyceraldehyde-3-phosphate dehydrogenase; NSAID, nonsteroidal anti-inflammatory drug; PGHS, prostaglandin G/H synthase.

J. Clin. Invest.

(C) The American Society for Clinical Investigation, Inc. 0021-9738/95/08/0923/08 \$2.00

Volume 96, August 1995, 923-930
(1-4). Bone cells produce bFGF at 10-fold higher levels than they produce acidic fibroblast growth factor (FGF) another heparin-binding factor that exhibits $\sim 55 \%$ sequence identity to bFGF $(5,6)$. Recently, we found that bFGF mRNA and protein are expressed in mouse osteoblastic MC3T3-E1 cells (7). bFGF is stored in the extracellular matrix in association with heparin sulfate and is activated by proteases or heparin-like molecules (8-10). bFGF could act as an autocrine/paracrine factor for bone cells. bFGF modulates bone formation through the regulation of proliferation and differentiation of cells of osteoblastic lineage in vitro (4). We have also reported that bFGF stimulates bone resorption in cultured fetal rat long bones (11).

Among prostaglandins ( $\mathrm{PGs}$ ), $\mathrm{PGE}_{2}$ is the major product of osteoblasts $(12,13)$ and is a potent bone resorber in vitro $(12,14,15) . \mathrm{PGE}_{2}$ also has mitogenic effects on bone cells $(16,17)$. Both exogenous bFGF (18-20) and PGE $_{2}(21-24)$ have been shown to stimulate new bone formation in vivo. In some cell lines, including fibroblasts and synovial cells, bFGF has been shown to stimulate PG production (25-27). Therefore, it is possible that some of the effects of bFGF on bone metabolism might be mediated by PG synthesis.

The major enzyme regulating the conversion of arachidonic acid (AA) to PGs is prostaglandin G/H synthase (PGHS), also called cyclooxygenase, which oxidizes $A A$ to $\mathrm{PGG}_{2}$ and reduces $\mathrm{PGE}_{2}$ to $\mathrm{PGH}_{2}$. Two forms of PGHS, constitutive PGHS (PGHS-1) and inducible PGHS (PGHS-2), have been identified. PGHS-1 mRNA has been identified in many ovine, murine, and human tissues (28), while the PGHS-2 mRNA was first found as an immediate-early gene from murine fibroblasts and chick embryo fibroblasts (29-31). These two enzymes have $60 \%$ homology in nucleic acid and amino acid sequence, although they are products of separate genes (28). Both are glycoproteins whose molecular weight is $70-74 \mathrm{kD}$. PGHS-1 is constitutively expressed, while the recently identified PGHS-2 is likely to be more important in regulating prostaglandin production by extracellular ligands. Both PGHS-1 and PGHS-2 are expressed in osteoblastic cells. PGHS-2 is the main enzyme regulating the production of $\mathrm{PGE}_{2}$ in response to hormones and cytokines in MC3T3-E1 cell cultures and neonatal mouse calvarial cultures (32-34).

The present study was undertaken to examine the effects of bFGF on PG production and the role of PGs in the response to bFGF in bone. Mouse osteoblastic MC3T3-E1 cells were used to investigate the cellular mechanisms by which bFGF regulates PG synthesis, and neonatal mouse calvarial cultures were used to examine the involvement of PGs in bFGF-stimulated bone resorption.

\section{Methods}

Materials. The PGHS-2 promoter-luciferase fusion genes containing either 963 or 371 bp of PGHS-2 5'-flanking sequence in pXp-2 vector 
(P2-Luc963 or P2-Luc371, respectively) have been described previously (35). Human recombinant bFGF was provided by California Biotechnology (Mountain View, CA). Murine PGHS-1 cDNA was the gift of Drs. David DeWitt and William Smith (Michigan State University, East Lansing, MI). Murine PGHS-2 cDNA was obtained from Oxford Biomedical Research Inc. (Oxford, MI). Polyclonal rabbit antimurine PGHS-2 antiserum was obtained from Cayman Chemical Co. (Ann Arbor, MI). Murine glyceraldehyde-3-phosphate dehydrogenase (GAPDH) cDNA was amplified by PCR using a mouse GAPDH control amplimer set from Clontech (Palo Alto, $\mathrm{CA}$ ). $\mathrm{PGE}_{2}$ antibody was purchased from Dr. Lawrence Levine (Waltham, MA). Other chemicals were obtained from Sigma Chemical Co. (St. Louis, MO).

Stable DNA transfection. The PGHS-2 promoter-luciferase fusion constructs contain either 963 or $371 \mathrm{bp}$ of the $5^{\prime}$ flanking sequence immediately proximal to the transcription start site and $70 \mathrm{bp}$ of downstream untranslated DNA (35). Promoterless luciferase vector was made by cutting P2-Luc371 with BamHI and BglII, followed by ligation with T4 ligase (GIBCO BRL, Gaithersburg, MD).

PGHS-2 promoter-reporter constructs were purified by $\mathrm{CsCl}$ banding and cotransfected with $\mathrm{pSV}_{2}$-neo into cultured MC3T3-E1 cells using Lipofectamine (GIBCO BRL). For transfection, MC3T3-E1 cells were plated in 6 well dishes (Costar Corp., Cambridge, MA) at $1 \times 10^{5}$ cells/well and grown to 50-80\% confluency (18-24 h) in DME without phenol red (Sigma) containing 10\% heat-inactivated FCS (GIBCO BRL), penicillin ( $100 \mathrm{U} / \mathrm{ml})$, and streptomycin $(50 \mu \mathrm{g} / \mathrm{ml})$. Cells were rinsed twice with serum-free medium and incubated with $1 \mu \mathrm{g}$ of promoter-reporter DNA, $0.067 \mu \mathrm{g}$ of $\mathrm{pSV}_{2}$-neo DNA, and $8 \mu \mathrm{l}$ of Lipofectamine reagent in $1 \mathrm{ml}$ of serum-free medium without antibiotics. After $5 \mathrm{~h}$ of incubation, a second $\mathrm{ml}$ of medium with $20 \%$ FCS was added; $19 \mathrm{~h}$ later the medium was replaced with fresh complete medium. After $48 \mathrm{~h}$, cells were split 1:10 into $100-\mathrm{mm}$ dishes and placed under selection with $400 \mu \mathrm{g} / \mathrm{ml}$ of G418 for $2 \mathrm{w}$. Stable colonies ( $>200$ ) were pooled to randomize effects of variation in integration site. Cells were grown in culture medium containing $200 \mu \mathrm{g} / \mathrm{ml} \mathrm{G} 418$.

Cell culture. MC3T3-E1 cells were plated in 6-well dishes (Costar Corp.) at a density of 50,000 cells $/ \mathrm{cm}^{2}$ unless stated otherwise and grown for 6-7 d in DME containing $10 \%$ heat-inactivated FCS and antibiotics. They were precultured for another $24 \mathrm{~h}$ in serum-free.DME with antibiotics, $1 \mathrm{mg} / \mathrm{ml}$ BSA (RIA grade; Sigma Chemical Co.), and $100 \mu \mathrm{g} / \mathrm{ml}$ phosphoascorbic acid ( $\mathrm{L}$-ascorbic acid phosphate magnesium salt; Wako Pure Chemical Industries, Osaka, Japan) before treatment. Cycloheximide was added $45 \mathrm{~min}$ before addition of bFGF. Control cultures were treated with appropriate vehicles. For test materials dissolved in ethanol, the final concentration of ethanol was $0.1 \%$.

PGHS-2 promoter activity. Luciferase activity was measured in soluble cell extracts prepared with a luciferase detection kit (Promega, Madison, WI) using an automatic injection luminometer (Analytical Luminescence Lab. Inc., San Diego, CA). Activity was normalized to total proteins measured with a BCA protein assay kit (Pierce, Rockford, IL). For each experiment, six wells were analyzed per treatment group, and data were expressed as means \pm SEM.

Neonatal mouse calvarial culture. Parietal bones were excised from 7-d-old CD-1 mice (Charles River Laboratories, Wilmington, MA). Bones were precultured for $24 \mathrm{~h}$ in a chemically defined medium, BGJb ( $1 \mathrm{mM}$ proline, $3 \mathrm{mM}$ phosphate, $0.4 \mathrm{mM}$ L-glutamine, $100 \mu \mathrm{g} / \mathrm{ml} \mathrm{L}$ ascorbic acid phosphate, and $1 \mathrm{mg} / \mathrm{ml} \mathrm{BSA}$ ) (GIBCO BRL). They were cultured in the experimental medium in 24 well dishes (Costar Corp.) on a rocking platform.

Bone resorption assay. Bone resorption was measured as the release of previously incorporated ${ }^{45} \mathrm{Ca}$ from neonatal mouse calvariae. Timed pregnant mice were injected with $0.05 \mathrm{mCi}^{45} \mathrm{Ca}$ on the 16 th day of gestation, and parietal bones were excised from 7-d-old neonatal mice. Bones were precultured in BGJb medium for 16-24 h and then cultured with experimental agents for $96 \mathrm{~h}$, with a medium change after $48 \mathrm{~h}$. Indomethacin or aphidicolin was added $2 \mathrm{~h}$ before addition of bFGF. ${ }^{45} \mathrm{Ca}$ in the medium and in TCA extracts of bone was determined by liquid scintillation counting. ${ }^{45} \mathrm{Ca}$ release in the medium was expressed as the percentage of total counts in the medium and bone extracts. Data from multiple experiments were pooled after individual values were normalized to the mean control for each experiment.

Steady state mRNA analysis. Three wells of cells in 6-well dishes or 6-8 half calvariae were pooled for RNA extraction using the method of Chomczynski and Sacchi (36). Briefly, cells or calvariae were homogenized in $4 \mathrm{M}$ guanidinium thiocyanate, extracted with phenol/ chloroform-isoamyl alcohol (24:1), and RNA precipitated with isopropanol and washed with $80 \%$ ethanol. After quantitation at $260 \mathrm{~nm}, 20$ $\mu \mathrm{g}$ of total RNA was run on a $1 \%$ agarose $-2.2 \mathrm{M}$ formaldehyde gel and transferred to a nylon membrane (Genescreen; New England Nuclear Research, Boston, MA) by positive pressure and fixed to the membrane by ultraviolet irradiation. After $3 \mathrm{~h}$ of prehybridization in a $50 \%$ formamide solution at $42^{\circ} \mathrm{C}$, filters were hybridized overnight in a similar solution in rotating cylinders at $42^{\circ} \mathrm{C}$ with a random primer $\left[{ }^{32} \mathrm{P}\right] \mathrm{dCTP}$ (New England Nuclear Research)-labeled cDNA probe for PGHS-1, PGHS-2, or GAPDH. Filters were washed in a $1 \times$ SSC, $1 \%$ SDS solution, $0.1 \times \mathrm{SSC}$, at room temperature. Then the filters were washed three times at $65^{\circ} \mathrm{C}$ with $0.1 \%$ SDS. The filters were exposed to XAR5 film (Eastman Kodak, Rochester, NY) at $-70^{\circ} \mathrm{C}$. Signals were quantitated by densitometry (Bio-Rad Laboratories, Richmond, CA), and optical densities for PGHS-1 and PGHS-2 were normalized to the corresponding values for GAPDH.

Western blot analysis. MC3T3-E1 cells were plated in 100-mm dishes (Costar Corp.) at a density of $5,000 \mathrm{cells} / \mathrm{cm}^{2}$ and grown to confluence in DME containing $10 \%$ serum. Cells were serum deprived for $24 \mathrm{~h}$ and treated for 2,6 , and $24 \mathrm{~h}$ with or without bFGF (10 nM). Cells were then washed with PBS, harvested by centrifugation, and extracted with $0.5 \%$ Tween 20 in a $20 \mathrm{mM}$ potassium phosphate buffer (pH 7.4) containing $1 \mathrm{mM}$ phenylmethyl-sulfonyl fluoride, $1 \mathrm{mM}$ EDTA, and $1 \mathrm{mM} N$-ethylmaleimide at $4^{\circ} \mathrm{C}$ for $30 \mathrm{~min}$. This mixture was centrifuged at $14,000 \mathrm{~g}$ for $30 \mathrm{~min}$. The supernatant was dialyzed against $N$-ethylmaleimide without Tween 20 for $16 \mathrm{~h}$, and an aliquot was mixed with DEAE cellulose (200- $\mu$ l bed volume/mg protein) preequilibrated with the potassium phosphate buffer containing $0.05 \%$ Tween 20 . DEAE cellulose was precipitated by centrifugation, and protein in the supernatant was measured by the BCA protein assay kit (Pierce). $25 \mu \mathrm{g}$ of protein per treatment group was run on an SDSpolyacrylamide gel ( $10 \%)$ and transferred to a polyvinylidene difluoride membrane. Membranes were incubated with $1 \%$ nonfat dry milk at $4{ }^{\circ} \mathrm{C}$ for $16 \mathrm{~h}$ to block nonspecific binding and then treated with a 1:2,000 dilution of polyclonal rabbit anti-PGHS-2 antiserum or nonimmune rabbit serum. Immunoreactive bands were stained using a Western exposure chemiluminescent detection kit (Clontech) according to the manufacturer's instructions.

Immunocytochemistry. MC3T3-E1 cells were plated on glass coverslips at a density of 5,000 cells $/ \mathrm{cm}^{2}$ and grown in DME with $10 \%$ FCS. When at least $80 \%$ confluent, cells were serum deprived for $24 \mathrm{~h}$ and then cultured for 6 or $24 \mathrm{~h}$ with or without bFGF (10 nM). Cells were fixed with $2 \%$ paraformaldehyde in PBS for $30 \mathrm{~min}$ at room temperature. Cells were rinsed twice for $10 \mathrm{~min}$ with PBS. Cells were permeabilized with $0.1 \%$ Triton X-100 for $20 \mathrm{~min}$ on ice (37). After a 20-min incubation with $0.1 \%$ gelatin in PBS, a 1:40 dilution of the rabbit anti-murine PGHS-2 antiserum or rabbit nonimmune serum was added to cells for $2 \mathrm{~h}$ at room temperature. A 1:200 dilution of rhodamine-conjugated anti-rabbit IgG was added to the cells for $1 \mathrm{~h}$ at room temperature. To prevent quenching of the fluorescence, $2.5 \% \mathrm{n}$-propyl gallate in 1:1 PBS:glycerol was added. The cells were photographed with a fluorescence microscope (Optiphot; Nikon Inc., Melville, NY).

$P G E_{2}$ assays. Medium was removed from cultured cells or bones, and $\mathrm{PGE}_{2}$ accumulation was measured by radioimmunoassay as described previously (38). In some instances indicated in the text, AA $(10 \mu \mathrm{M})$ was added to MC3T3-E1 cell culture to provide substrate for $\mathrm{PGE}_{2}$ production.

Statistical analysis. Means of groups were compared using ANOVA, and significance of differences was determined by post-hoc testing using Bonferroni's method.

\section{Results}

PGHS-2 mRNA was undetectable in unstimulated MC3T3-E1 cells, but was rapidly induced by bFGF ( $10 \mathrm{nM})$. mRNA levels 


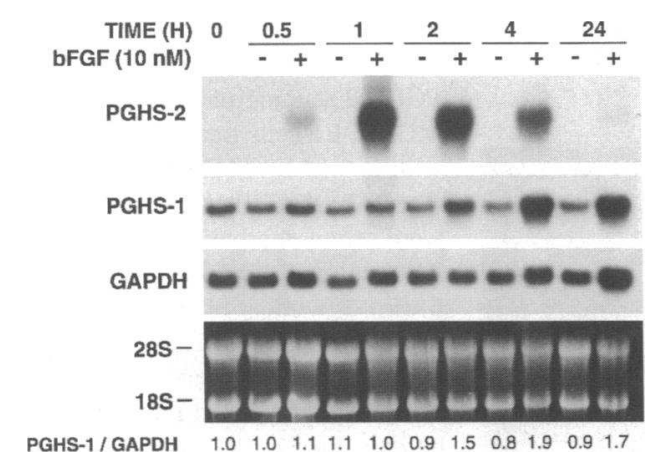

Figure 1. Time course of the effect of bFGF on steady state mRNA levels of PGHS-2 and PGHS-1 in MC3T3-E1 cells. MC3T3-E1 cells were serum deprived for $24 \mathrm{~h}$ and cultured with or without bFGF (10 $\mathrm{nM}$ ) for the time indicated. Total RNA was extracted and $20 \mu \mathrm{g}$ of RNA was fractionated on a $1 \%$ agarose gel, transferred to nylon filters, and hybridized to PGHS-2, PGHS-2, and GAPDH. The numbers on the bottom are the treated/control ratios of the intensity of PGHS-1 normalized to that of GAPDH measured by densitometry.

were maximal at $1 \mathrm{~h}$, remained elevated for at least $4 \mathrm{~h}$, and then decreased over the next $24 \mathrm{~h}$ (Fig. 1). Fig. 2 shows the dose response of the effect of bFGF on PGHS-2 mRNA at $1 \mathrm{~h}$ of treatment in cells initially plated at different densities $(5,000$ and 50,000 cells $/ \mathrm{cm}^{2}$ ). PGHS-2 mRNA was induced with $10^{-10}$ $\mathrm{M}$ bFGF, and accumulation was maximal at $10^{-9} \mathrm{M}$. These effects were independent of the plating density. PGHS-1 mRNA was expressed constitutively and was not altered by $1 \mathrm{~h}$ of treatment with bFGF (Figs. 1 and 2). Stimulation of PGHS-1 by bFGF only appeared after $2 \mathrm{~h}$ and was less than twofold when normalized to GAPDH mRNA. Cycloheximide ( $3 \mu \mathrm{g} /$ $\mathrm{ml}$ ), a protein synthesis inhibitor, induced PGHS-2 mRNA and potentiated the effect of bFGF (Fig. 3), indicating that new protein synthesis is not essential for the stimulatory effect of bFGF.

PGHS-2 protein levels in MC3T3-E1 cells were measured by Western blotting (Fig. 4). Immunoreactive protein was induced by bFGF ( $10 \mathrm{nM})$ at $2 \mathrm{~h}$ and was still present at $24 \mathrm{~h}$. Multiple bands were present at $24 \mathrm{~h}$, perhaps due to deglycosylation during culture (39). The localization of PGHS-2 protein was examined by immunocytochemistry at 6 and $24 \mathrm{~h}$ of culture (Fig. 5). Immunofluorescence microscopy demonstrated an increase in cytoplasmic PGHS-2 levels at $6 \mathrm{~h}$ with bFGF (10 $\mathrm{nM}$ ). Staining was still present at $24 \mathrm{~h}$. The nuclear staining

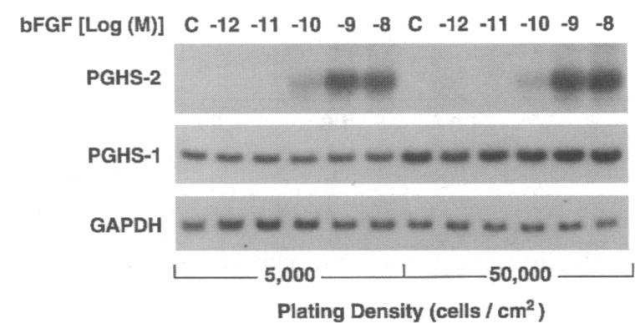

Figure 2. Dose response of the effect of bFGF on steady state mRNA levels of PGHS-2 and PGHS-1 in MC3T3-E1 cells at $1 \mathrm{~h}$ of culture. Cells were plated at 5,000 or 50,000 cells $/ \mathrm{cm}^{2}$ and cultured for $6 \mathrm{~d}$. Cells were serum deprived for $24 \mathrm{~h}$ and cultured for $1 \mathrm{~h}$ with various concentrations of bFGF. $20 \mu \mathrm{g}$ of RNA was hybridized to PGHS-2, PGHS-1, and GAPDH.
Figure 3. Effect of cycloheximide (CHX) on steady state mRNA levels of PGHS-2 and PGHS-1 in the presence and absence of bFGF in MC3T3-E1 cells. Cells were precultured for $24 \mathrm{~h}$ and cultured for $1 \mathrm{~h}$ with bFGF ( $10 \mathrm{nM}$ ) in the presence and absence of cycloheximide $(3 \mu \mathrm{g} / \mathrm{ml})$. Cycloheximide was pulsed into the culture 45 min before bFGF treatment. $20 \mu \mathrm{g}$ of RNA was hybridized to PGHS-2, PGHS-1, and GAPDH.

seen in control cultures was also seen with preimmune serum (data not shown), indicating that this was nonspecific.

Medium $\mathrm{PGE}_{2}$ was not detectable $(<0.1 \mathrm{nM})$ in serumfree cell cultures, despite the constitutive expression of PGHS1 mRNA and the induction of PGHS-2 by bFGF. However, if cells were given exogenous AA $(10 \mu \mathrm{M})$, the substrate for both PGHS-1 and PGHS-2, during the last $10 \mathrm{~min}$ of culture, $\mathrm{PGE}_{2}$ production was increased by $\mathrm{bFGF}(10 \mathrm{nM})$ treatment as early as $2 \mathrm{~h}$ (Table $\mathrm{I}$ ).

To examine the transcriptional regulation of PGHS-2 by bFGF, PGHS-2 promoter-luciferase fusion genes containing 963 or 371 bp of $5^{\prime}$ flanking sequence (P2-Luc 963 or P2-Luc 371 , respectively) were stably transfected into MC3T3-E1 cells. Basic FGF (10 nM) stimulated luciferase activity in P2-Luc 963 and P2-Luc 371 to a similar extent at $3 \mathrm{~h}$ (treated/control ratios for luciferase activity were $4.7 \pm 0.3$ and $4.9 \pm 0.1$, respectively), suggesting that a bFGF response element is likely to reside within the proximal 371 bp. Fig. 6 shows the time course of the effect of bFGF on luciferase activity in cells transfected with P2-Luc 371. Significant stimulation was observed at $1 \mathrm{~h}$, reached a maximum at $2-3 \mathrm{~h}$, and decreased to the control level at $24 \mathrm{~h}$.

Luciferase activity of P2-Luc 371 transfected cells and promoterless-Luc transfected cells were measured with or without bFGF at $3 \mathrm{~h}$ of culture at different plating densities of 5,000 and 50,000 cells $/ \mathrm{cm}^{2}$ (Fig. 7). Cells were cultured continuously in the presence of arachidonic acid $(10 \mu \mathrm{M})$, and medium $\mathrm{PGE}_{2}$ levels were also measured at $3 \mathrm{~h}$. There were similar dosedependent responses for both luciferase activity and $\mathrm{PGE}_{2}$ lev-

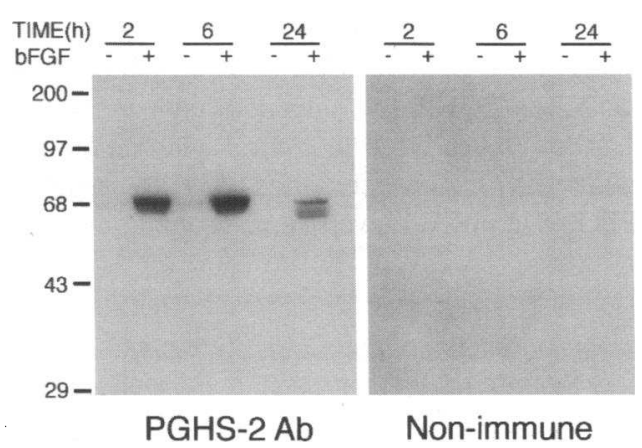

Figure 4. Time course of the effect of bFGF on immunoreactive PGHS2 protein in MC3T3-E1 cells. Cells were serum deprived for $24 \mathrm{~h}$ and then treated for 2,6 , and $24 \mathrm{~h}$ with or without bFGF ( $10 \mathrm{nM})$. Proteins were extracted as shown in Methods, and $25 \mu \mathrm{g}$ of protein was loaded on a $10 \%$ SDS-polyacrylamide gel and transferred to a polyvinylidene difluoride membrane. Membranes were incubated with $1 \%$ nonfat dry milk to block nonspecific binding and then with polyclonal rabbit antimurine PGHS-2 antiserum or nonimmune rabbit serum (both 1:2,000 dilutions). Immunoreactive bands were stained using alkaline phosphatase immunostaining and detected by chemiluminescence. 


\section{Control}
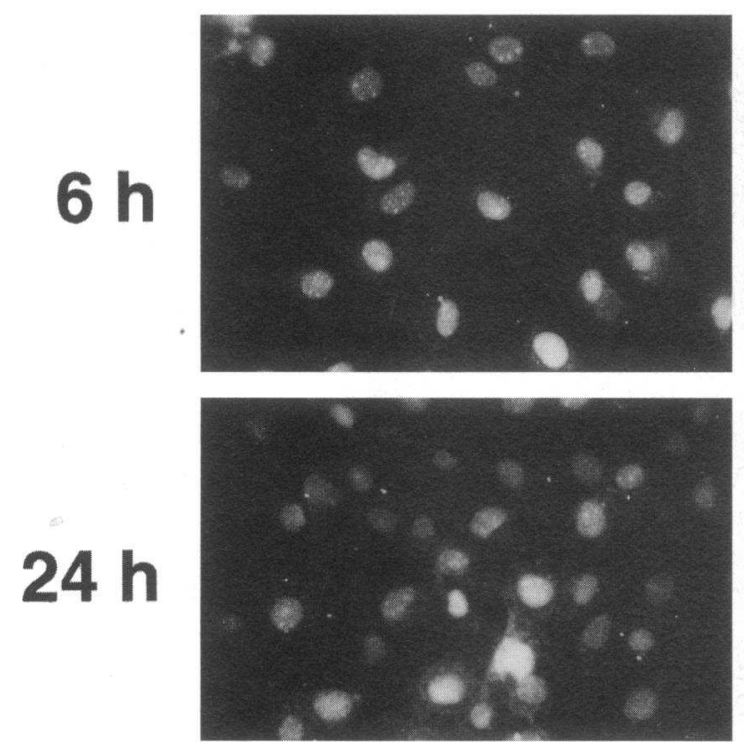

\section{bFGF}
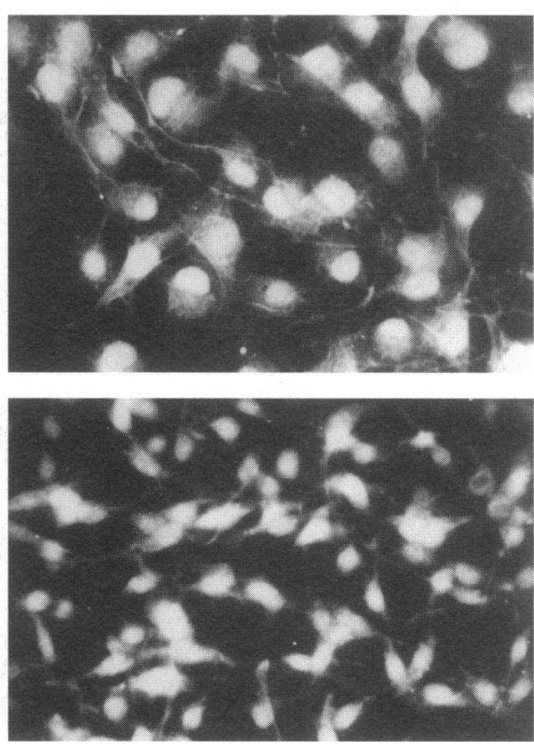

Figure 5. Immunofluorescence microscopy of PGHS-2 staining in MC3T3-E1 cells treated with or without bFGF for 6 or 24 h. MC3T3-E1 cells were serum-deprived for $24 \mathrm{~h}$, cultured for 6 or 24 $\mathrm{h}$ with or without bFGF $(10 \mathrm{nM})$, and then fixed, permeabilized, and incubated with polyclonal rabbit anti-murine PGHS-2 antiserum or nonimmune rabbit serum and then treated with rhodamineconjugated anti-rabbit IgG. An increase in PGHS2 staining is apparent in the cytoplasm of the cells. The nuclear staining which is seen in control cultures was also observed in nonimmune cells $\times 200$ (data not shown). els. There was an increase in $\mathrm{PGE}_{2}$ production with bFGF (10 $\mathrm{nM}$ ) of 10-fold or more and an increase in PGHS-2 promoter activity of sevenfold or more. The similarities in these responses, along with the twofold or less increase in PGHS-1 mRNA levels at $3 \mathrm{~h}$ (Fig. 1), suggest that the stimulation of $\mathrm{PGE}_{2}$ production was largely dependent on transcriptional regulation of PGHS-2. Plating density did not influence bFGF's effect on either $\mathrm{PGE}_{2}$ production or PGHS-2 promoter activity. Cells transfected with the promoterless luciferase construct showed minimal luciferase activity, but produced $\mathrm{PGE}_{2}$ levels similar to the P2-Luc 371 transfected cells.

The neonatal mouse calvarial culture system can be used to examine and compare physiological responses of bone cells (such as cellular proliferation), bone formation (measured by collagen synthesis), and bone resorption (measured by ${ }^{45} \mathrm{Ca}$ release from prelabeled calvariae). Because bFGF and $\mathrm{PGE}_{2}$ have similar effects on some responses, we used the calvarial culture system to determine if $\mathrm{PGE}_{2}$ mediated these responses to bFGF. 7-d-old neonatal mouse calvariae were cultured in serum-free media. PGHS-2 mRNA was not detectable in freshly dissected calvariae but was induced in control cultures during the first $24 \mathrm{~h}$ in culture, as previously reported (33). The spontaneously induced PGHS-2 mRNA levels in control cultures de-

Table I. PGE 2 Production by Serum-free MC3T3-E1 Cells Treated for $2 \mathrm{~h}$ with $\mathrm{bFGF}(10 \mathrm{nM})$ and for the Last $10 \mathrm{~min}$ of Culture with Arachidonic Acid $(A A ; 10 \mu M)$ or Vehicle (Ethanol)

\begin{tabular}{lc}
\hline \multicolumn{1}{c}{ Treatment } & $\mathrm{PGE}_{2}(\mathrm{nM})$ \\
\hline Control & $<0.1$ \\
bFGF & $<0.1$ \\
Control + AA & $6.2 \pm 3.6$ \\
bFGF + AA & $16.0 \pm 3.6^{*}$ \\
\hline
\end{tabular}

Values are means \pm SEM; $n=3$. $*$ Significantly different from control $+\mathrm{AA} ; P<0.05$. creased after $24 \mathrm{~h}$ of culture, eventually becoming undetectable. Hence, the calvariae were given a $24 \mathrm{~h}$ preculture in control media to allow the spontaneous induction of PGHS-2 mRNA to decrease so as not to obscure induction by bFGF. After preculture, calvariae were placed in culture with or without bFGF and cultured for another $96 \mathrm{~h}$, with a medium change after $48 \mathrm{~h}$ (Figs. 8 and 9). At the beginning of treatment, control cultures still had elevated levels of PGHS-2 mRNA (Figs. $8 \mathrm{~A}$ and 9). bFGF stimulated PGHS-2 mRNA levels with a biphasic time course. Levels peaked at 2-4 h, decreased to undetectable at $24 \mathrm{~h}$, and then increased again at $48 \mathrm{~h}$. After a change to fresh

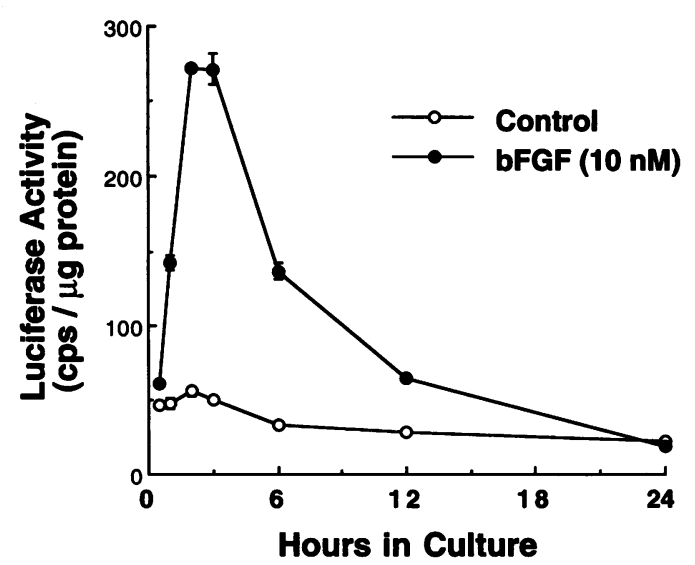

Figure 6. Time course of the effect of bFGF on PGHS-2 promoter activity of MC3T3-E1 cells stably transfected with the 371-bp PGHS2 promoter-luciferase fusion construct (P2-Luc 371). Cells were stably transfected with a PGHS-2 promoter-luciferase fusion construct containing $371 \mathrm{bp}$ of the $5^{\prime}$ flanking sequence and $70 \mathrm{bp}$ of downstream untranslated DNA, and selected with G418 as described in Methods. Transfected cells were serum deprived for $24 \mathrm{~h}$ and treated with or without bFGF (10 $\mathrm{nM}$ ) for the time indicated. Assay for luciferase activity was done on soluble cell extracts and normalized to total proteins. Symbols indicate means and the vertical bar; SEM for 3-6 wells. 

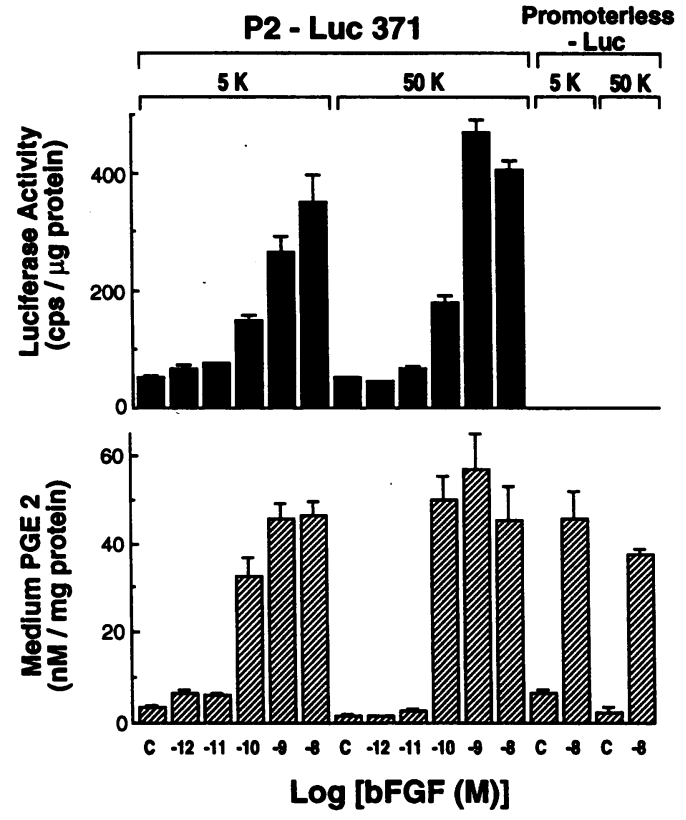

Figure 7. Dose response of the effect of bFGF at $3 \mathrm{~h}$ on PGHS-2 promoter activity and medium $\mathrm{PGE}_{2}$ levels in MC3T3-E1 cell culture stably transfected with P2-Luc 371 or a promoterless luciferase. Cells were plated at 5,000 or 50,000 cells $/ \mathrm{cm}^{2}$ and cultured for $6 \mathrm{~d}$. Cells were serum deprived for $24 \mathrm{~h}$ and cultured for $3 \mathrm{~h}$ with various concentrations of bFGF. The assay for luciferase activity was performed on soluble cell extracts and normalized to total proteins. Medium PGE $_{2}$ was measured by radioimmunoassay in the presence of AA $(10 \mu \mathrm{M})$.

media with bFGF, PGHS- 2 mRNA levels were again elevated at $96 \mathrm{~h}$. PGHS-1 mRNA levels were also stimulated by bFGF but only after $4 \mathrm{~h}$, and this increase was maintained. In contrast with MC3T3-E1 cell cultures, measurable $\mathrm{PGE}_{2}$ accumulated in the medium without the addition of arachidonic acid. A doseresponse study showed that at $4 \mathrm{~h}$, the induction of PGHS-2 and PGHS-2 mRNA and $\mathrm{PGE}_{2}$ production were maximum at bFGF $1 \mathrm{nM}$ (Fig. 8 B).

In addition to the 4.2-kb PGHS-2 band, a smaller ( $2.5 \mathrm{~kb})$

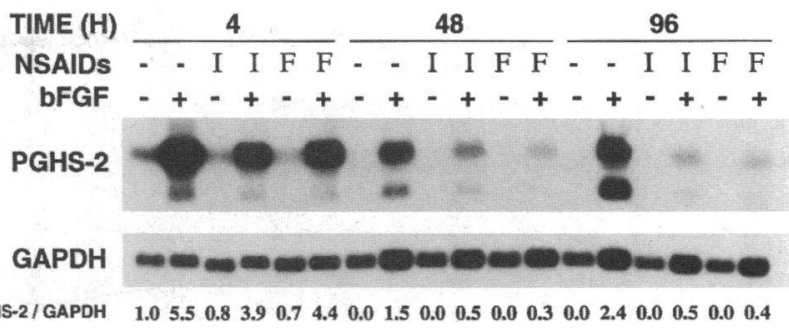

Figure 9. Effects of two structurally unrelated NSAIDs, indomethacin and flurbiprofen, on bFGF-stimulated PGHS-2 mRNA levels in cultured neonatal mouse calvariae at 4,48 , and $96 \mathrm{~h}$. Calvariae were precultured for $24 \mathrm{~h}$ and cultured with or without bFGF $(1 \mathrm{nM})$ for the time indicated. $1 \mu \mathrm{M}$ indomethacin (I) and $1 \mu \mathrm{M}$ flurbiprofen (F) were added $2 \mathrm{~h}$ before adding bFGF. Total RNA was extracted, and $20 \mu \mathrm{g}$ of RNA was fractionated on a $1 \%$ agarose gel, transferred to nylon filters, and hybridized to PGHS-2 and GAPDH.

mRNA was present in RNA extracted from calvariae treated for $48 \mathrm{~h}$ with bFGF. This band increased at $96 \mathrm{~h}$. The smaller band probably reflects a different site of polyadenylation of PGHS-2 mRNA as reported previously for murine PGHS-2 (40).

Because we have previously found that endogenous prostaglandins can stimulate PGHS-2 mRNA in both MC3T3-E1 cells $(32,41)$ and mouse calvarial cultures $(33)$, we examined the effects of two structurally unrelated nonsteroid anti-inflammatory drugs (NSAIDs) indomethacin and flubiprofen (both at 1 $\mu \mathrm{M}$ ) on the induction of PGHS-2 in mouse calvariae cultures by bFGF (Fig. 9). At $4 \mathrm{~h}$ the induction was only slightly inhibited. At 48 and $96 \mathrm{~h}$, both NSAIDs inhibited the bFGF induction of PGHS- 2 mRNA accumulation by about $80 \%$, suggesting that the recurrence of PGHS-2 induction at later time points was probably due to autoamplification by the production of prostaglandins.

Both bFGF and $\mathrm{PGE}_{2}$ can have potent effects on osteoblastic proliferation and synthesis of collagen. We have previously reported that bFGF inhibited collagen synthesis in MC3T3-E1 cells but that this inhibition was not PG dependent (42). In the present study, we examined the effect of bFGF (10 $\mathrm{nM})$ on

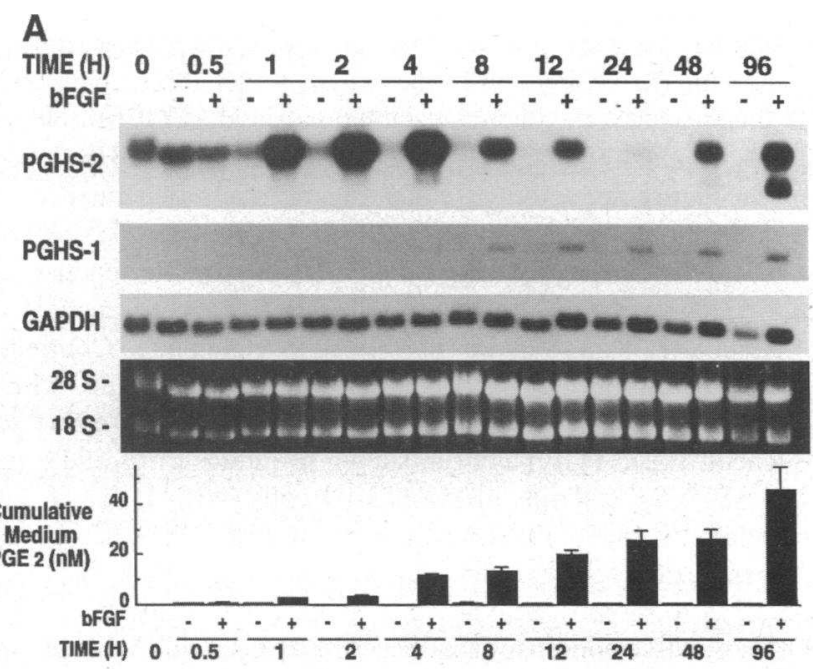

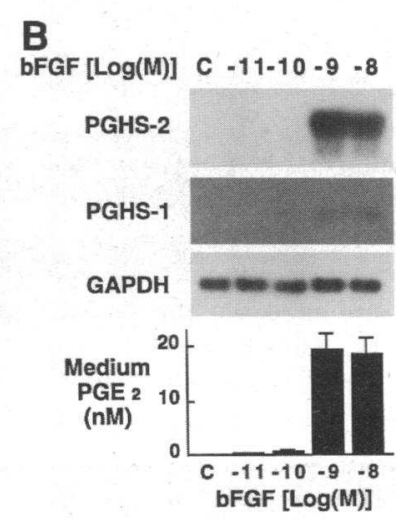

Figure 8. (A) Time course of the effect of bFGF on steady state mRNA levels of PGHS-2 and PGHS- 1 in cultured neonatal mouse calvariae. 7-dold neonatal mouse calvariae were precultured for $24 \mathrm{~h}$ and cultured with or without $\mathrm{bFGF}(1 \mathrm{nM})$ for the time indicated. Time 0 is time of $\mathrm{bFGF}$ addition. Total RNA was extracted and $20 \mu \mathrm{g}$ of RNA was fractionated on a $1 \%$ agarose gel, transferred to nylon filters, and hybridized to the probes for PGHS-2, PGHS-1, and GAPDH. $(B)$ Dose response of the effect of bFGF on steady state mRNA levels of PGHS- 2 and PGHS- 1 in cultured neonatal mouse calvariae at $4 \mathrm{~h}$ of culture. Calvariae were precultured for $24 \mathrm{~h}$ and then treated for $4 \mathrm{~h}$ with various concentrations of bFGF. 20 $\mu \mathrm{g}$ of RNA was hybridized to PGHS2 , PGHS-1, and GAPDH. 


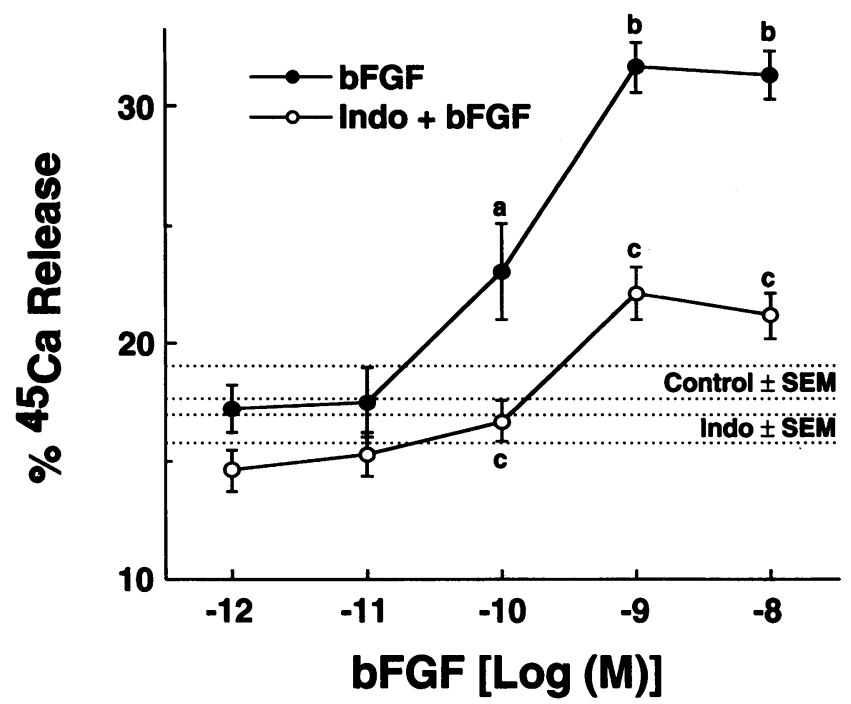

Figure 10. Dose response of the effect of bFGF on ${ }^{45} \mathrm{Ca}$ release from prelabeled neonatal mouse calvariae in the presence and absence of indomethacin at $96 \mathrm{~h}$ of culture. ${ }^{45} \mathrm{Ca}$ prelabeled calvariae were precultured for 16-24 h and then cultured with experimental agents for $96 \mathrm{~h}$ with a medium change after $48 \mathrm{~h}$. Treatment with indomethacin $(1 \mu \mathrm{M})$ was begun $2 \mathrm{~h}$ before the addition of bFGF $(1 \mathrm{nM}) .{ }^{45} \mathrm{Ca}$ in medium and TCA extracts of bone was determined by liquid scintillation counting and the cumulative percentage of ${ }^{45} \mathrm{Ca}$ release was calculated. Data from multiple experiments were pooled after calculating individual values as a percentage of the mean control for each experiment. Similar results were seen at $48 \mathrm{~h}$ of culture, although bFGF stimulation was less than that at 96 h. $a$, significant effect of bFGF: $P<0.05 . b, P$ $<0.01$. $c$, significant effect of indomethacin: $P<0.01$.

$\left[{ }^{3} \mathrm{H}\right]$ thymidine (TdR) incorporation into MC3T3-E1 cells and cultured mouse calvariae in the presence and absence of indomethacin $(1 \mu \mathrm{M})$. bFGF stimulated $\left[{ }^{3} \mathrm{H}\right] \mathrm{TdR}$ incorporation in both cell and organ culture $(4.6 \pm 0.5$-fold and $3.8 \pm 0.2$-fold, respectively) at $24 \mathrm{~h}$, and this stimulation was not inhibited by indomethacin in either system $(4.7 \pm 0.5$-fold and $3.8 \pm 0.2$-fold, respectively).

Both $\mathrm{bFGF}$ and $\mathrm{PGE}_{2}$ are potent stimulators of bone resorption. To examine the possible role of $\mathrm{PGE}_{2}$ in bFGF-stimulated resorption, we measured ${ }^{45} \mathrm{Ca}$ release from prelabeled neonatal mouse calvariae at 48 and $96 \mathrm{~h}$ of culture. Medium $\mathrm{PGE}_{2}$ accumulation was also measured at these time points, in the absence of exogenous arachidonic acid. bFGF increased the release of ${ }^{45} \mathrm{Ca}$ dose dependently, with a maximal increase of $80 \%$ at 1 $\mathrm{nM}$ after $96 \mathrm{~h}$ of culture (Fig. 10 and Table II). Indomethacin $(1 \mu \mathrm{M})$ blocked $\mathrm{PGE}_{2}$ production, abrogated the effect of bFGF $0.1 \mathrm{nM}$, and decreased the effects of higher concentrations of bFGF, suggesting that bFGF effects on bone resorption are partially dependent on PG production. Similar results were seen at $48 \mathrm{~h}$ of culture (data not shown).

To examine the role of the mitogenic effect of bFGF in bone resorption, we added $30 \mu \mathrm{M}$ aphidicolin (APC), an inhibitor of DNA synthesis, to the neonatal mouse calvarial cultures. At 48 and $96 \mathrm{~h}, \mathrm{APC}$ decreased $\left[{ }^{3} \mathrm{H}\right] \mathrm{TdR}$ incorporation into calvariae by $92-96 \%$ (data not shown). bFGF still increased bone resorption in the presence of APC (Table II). However, APC alone increased $\mathrm{PGE}_{2}$ production and bone resorption; both effects were blocked by indomethacin (Table II). Therefore, we added both APC and indomethacin and found that the combination abrogated the effects of bFGF on bone resorption.
Table II. Effects of bFGF $\left(10^{-9} \mathrm{M}\right)$ on ${ }^{45} \mathrm{Ca}$ Release from Prelabeled Neonatal Mouse Calvariae and Medium PGE Level $^{-6}$ in the Presence and Absence of Indomethacin (Indo: $10^{-6} \mathrm{M}$ ) and/or Aphidicolin (APC; $3 \times 10^{-5} \mathrm{M}$ )

\begin{tabular}{|c|c|c|c|c|}
\hline \multirow[b]{2}{*}{ Treatment } & \multicolumn{3}{|c|}{${ }^{45} \mathrm{Ca}$ release (\% of control) } & \multirow{2}{*}{$\begin{array}{l}\text { Medium } \\
\text { PGE }_{2} \\
(\mathrm{nM})\end{array}$} \\
\hline & $n$ & $48 \mathrm{~h}$ & $96 \mathrm{~h}$ & \\
\hline Control & 32 & $100 \pm 4$ & $100 \pm 4$ & $0.7 \pm 0.1$ \\
\hline bFGF & 32 & $155 \pm 5(55 \%)^{* 8}$ & $180 \pm 5(80 \%)^{* 8}$ & $36.6 \pm 6.7 * 8$ \\
\hline Indo & 21 & $85 \pm 4^{\ddagger}$ & $92 \pm 4$ & N.D. \\
\hline Indo + bFGF & 20 & $110 \pm 6(29 \%)^{8}$ & $124 \pm 6(36 \%)^{* 8}$ & N.D. \\
\hline APC & 24 & $131 \pm 5 *$ & $142 \pm 7 *$ & $7.3 \pm 1.6 *$ \\
\hline $\mathrm{APC}+\mathrm{bFGF}$ & 24 & $146 \pm 4(12 \%)^{*}$ & $187 \pm 5(32 \%)^{* 8}$ & $143.0 \pm 23.3^{* 8}$ \\
\hline Indo + APC & 19 & $95 \pm 7$ & $102 \pm 6$ & N.D. \\
\hline \multicolumn{5}{|l|}{ Indo + APC } \\
\hline+ bFGF & 19 & $105 \pm 4(11 \%)$ & $105 \pm 4(3 \%)$ & N.D. \\
\hline
\end{tabular}

Values are the mean \pm SEM for $n$ bone cultures. Data for ${ }^{45} \mathrm{Ca}$ release were normalized to 100 for those of the control. The mean control values of the percentage of ${ }^{45} \mathrm{Ca}$ release were $11.9 \pm 0.4 \%$ for $48 \mathrm{~h}$ and $17.8 \pm 0.7 \%$ for $96 \mathrm{~h}$ of culture. The data in parentheses indicate the percentage of stimulation of ${ }^{45} \mathrm{Ca}$ release produced by bFGF. Medium $\mathrm{PGE}_{2}$ was measured at $2 \mathrm{~d}$ of culture. * Significant difference from control; $P<0.01$. ${ }^{\ddagger} P<0.05$. ${ }^{8}$ Significant effect of bFGF; $P<0.01$. N.D., not detectable $(<0.1 \mathrm{nM})$.

\section{Discussion}

This study has shown that bFGF is a potent stimulator of PGHS2 mRNA and protein accumulation in osteoblastic MC3T3-E1 cells. In these cells, PGHS-2 mRNA was not detectable under control conditions. In contrast, PGHS-1 mRNA was constitutively expressed. Basic FGF transiently induced PGHS-2 mRNA in MC3T3-E1 cells, with levels peaking at $1 \mathrm{~h}$ and undetectable at $24 \mathrm{~h}$. This induction was not blocked by cycloheximide. The induction of PGHS-2 mRNA was accompanied by induction of PGHS-2 protein, which was still detectable at 24 h. In MC3T3-E1 cells stably transfected with a 371-bp PGHS-2 promoter-luciferase reporter construct, bFGF also rapidly and transiently stimulated luciferase activity. We conclude that bFGF regulates PGHS-2 expression in large part through a transcriptional mechanism. Despite the induced expression of PGHS-2, PGE $_{2}$ production was not measurable $(<0.1 \mathrm{nM})$ up to $24 \mathrm{~h}$ in these cultures unless arachidonic acid was given as substrate, suggesting that substrate release may be a limiting factor for PG production in these cells under these conditions. In the presence of exogenous arachidonic acid, bFGF-stimulated $\mathrm{PGE}_{2}$ production paralleled the stimulation of PGHS-2 promoter-luciferase activity, indicating a major dependence on transcriptional regulation of PGHS-2.

The 5' flanking region of the PGHS-2 promoter containing the 371-bp proximal to the transcription start site appears to contain one or more major bFGF response elements. Computer search of this region has identified an AP-1-like site, which may bind the Fos-Jun dimer and two NF-IL6 consensus sequences. Basic FGF has been shown to induce c-fos and c-jun and NF-IL6 transcripts in MC3T3-E1 cells $(43,44)$. However, maintaining the bFGF induction of pPGHS-2 mRNA in the presence of cycloheximide suggests that the major effect of bFGF is to directly activate one or more transcription factors. Other putative consensus sequences identified within this region 
include an SP-1 site, an ATF/CRE region, and an E-box or helix-loop-helix protein-binding element. The ATF/CRE site has been recently shown to mediate $v$-src induction of the murine PGHS-2 promoter (45).

Basic FGF also rapidly stimulated PGHS-2 mRNA levels in neonatal mouse calvarial cultures. Basic FGF increased medium $\mathrm{PGE}_{2}$ levels in these cultures, which were measurable in the absence of exogenous substrate, and stimulation of $\mathrm{PGE}_{2}$ production paralleled the stimulation of PGHS-2 mRNA expression. The mitogenic effects of bFGF in MC3T3-E1 cells and the inhibitory effects of bFGF on collagen synthesis in MC3T3E1 cells (42) have been shown to be independent of PG production. However, in the present study, the inhibition of $P G$ production by NSAIDs reduced bFGF-stimulated resorption in neonatal mouse calvariae, indicating that the resorptive effect of bFGF was mediated in part by PGs. Although an inhibitor of DNA synthesis alone did not block PG-mediated resorption, inhibition of both DNA synthesis and PG production completely blocked bFGF-stimulated resorption. Hence, we propose that bFGF has a direct effect on resorption through stimulation of proliferation of osteoclast precursors and an indirect effect mediated by PGs. We have shown by histological examination that bFGF increases the number of osteoclast-like cells in cultures of 21-d fetal rat calvariae (46). In a previous study in cultured fetal rat long bones, we found that bFGF-stimulated bone resorption was independent of PGs (11). Many stimulators of resorption show different degrees of dependence on endogenous prostaglandin production in different model systems, and even in the same model systems. In general, endogenous prostaglandin production is more likely to play a role in resorptive responses in neonatal mouse calvariae than in fetal rat long bones. Similar observations have been made for thyroid hormone (47) and interleukin $1(48,49)$. These differences may reflect the fact that the two culture systems contain a different population of osteoclast precursor cells or differences in other cell populations, particularly since the neonatal mouse calvariae contain some hematopoetic marrow, while fetal rat long bones do not.

Although the induction of PGHS-2 mRNA by bFGF in calvarial cultures had decayed by $24 \mathrm{~h}$, there was a rebound induction at 48 and $96 \mathrm{~h}$. This rebound could be inhibited by treatment with NSAIDs and hence was probably due largely to autoamplification by endogenous PGs. Autoamplification, perhaps in conjunction with the smaller, slower, but more sustained increases in PGHS-1 expression, may play an important role in maintaining physiologic responses mediated by PGs, such as bFGFstimulated resorption, which are initiated by transient inductions of PGHS-2 expression.

\section{Acknowledgments}

We thank Olga Voznesensky, Kristina Marcello, and Cynthia Alander for their expert technical assistance. We also thank Dr. Yoshinori Itoh for helpful discussion of experimental protocols.

\section{References}

1. Gospodarowicz, D., N. Ferrara, L. Schweigerer, and G. Neufeld. 1987. Structural characterization and biological functions of fibroblast growth factor. Endocr. Rev. 8:95-114.

2. Thomas, K. A. 1987. Fibroblast growth factors. FASEB (Fed. Am. Soc. Exp. Biol.) J. 1:434-440.

3. Rifkin, D. B., and D. Moscatelli. 1989. Recent development in the cell biology of basic fibroblast growth factor. J. Cell Biol. 109:1-6.

4. Canalis, E., M. Centrella, and T. L. McCarthy. 1988. Effects of basic fibroblast growth factor in vitro. J. Clin. Invest. 81:1572-1577.
5. Seyedin, S. M., T. C. Thomas, A. Y. Thompson, D. M. Rosen, and K. A. Diez. 1985. Purification and characterization of two cartilage-inducing factors from bovine demineralized bone. Proc. Natl. Acad. Sci. USA. 82:2267-2271.

6. Globus, R. K., J. Plouet, and D. Gospodarowicz. 1989. Cultured bovine bone cells synthesize fibroblast growth factor and store it in their extracellular matrix. Endocrinology. 124:1539-1547.

7. Hurley, M. M., C. Abreu, G. A. Gronowicz, H. Kawaguchi, and J. A. Lorenzo. 1994. Expression and regulation of basic fibroblast growth factor mRNA levels in mouse osteoblastic MC3T3-E1 cells. J. Biol. Chem. 269:9392-9396.

8. Bashkin, P., S. Doctrow, M. Klagsbrun, C. M. Svahn, J. Folkman, and I. Vlodavsky. 1989. Basic fibroblast growth factor binds to subendothelial matrix and is released by heparitinase and heparin-like molecules. Biochemistry. 28:1737-1743

9. Saksela, O., and D. Rifkin. 1990. Release of basic fibroblast growth factorheparin sulfate complexes from endothelial cells by plasminogen activator-mediated proteolytic activity. J. Cell Biol. 110:767-775.

10. Hauschka, P. V., A. E. Mavrakos, M. D. Iafrati, S. E. Doleman, and M. Klagsburn. 1986. Growth factors in bone matrix: isolation of multiple types of affinity chromatography on heparin sepharose. J. Biol. Chem. 261:12665-12674.

11. Simmons, H. A., and L. G. Raisz. 1991. Effects of acid and basic fibroblast growth factor and heparin on resorption of cultured fetal rat long bones. J. Bone. Miner. Res. 6:1301-1305.

12. Kawaguchi, H., C. C. Pilbeam, J. R. Harrison, and L. G. Raisz. The role of prostaglandins in the regulation of bone metabolism. Clin. Orthop. Relat. Res. In press.

13. Raisz, L. G., J. Y. Vanderhoek, H. A. Simmons, B. E. Kream, and K. C. Nicolaou. 1979. Prostaglandin synthesis by fetal rat bone in vitro: evidence for a role of prostacyclin. Prostaglandins. 17:905-914.

14. Klein, D. C., and L. G. Raisz. 1970. Prostaglandins: stimulation of bone resorption in tissue culture. Endocrinology. 86:1436-1440.

15. Raisz, L. G., and F. N. Woodiel. 1989. Effects of alteration in the cyclopentane ring on bone resorptive activity of prostaglandin. Prostaglandins. 37:229236.

16. Hakeda, Y., T. Yoshino, Y. Nakatani, N. Kurihara, N. Maeda, and M. Kumegawa. 1986. Prostaglandin $\mathrm{E}_{2}$ stimulates DNA synthesis by a cyclic AMPindependent pathway in osteoblastic clone MC3T3-E1 cells. J. Cell. Physiol. 128:155-161.

17. Feyen, J. H. M., A. Di Bon, A. Van der Plas, C. W. G. M. Lowick, and P. J. Nijweide. 1985. Effects of exogenous prostanoids on the proliferation of osteoblast-like cells in vitro. Prostaglandins. 30:827-840.

18. Kawaguchi, H., T. Kurokawa, K. Hanada, Y. Hiyama, M. Tamura, E. Ogata, and T. Matsumoto. 1994. Stimulation of fracture repair by recombinan human basic fibroblast growth factor in normal and streptozotocin-diabetic rats. Endocrinology. 135:774-781.

19. Mayahara, H., T. Ito, H. Nagai, H. Miyajima, R. Tsukuda, S. Taketomi, J. Mizoguchi, and K. Kata. 1993. In vivo stimulation of endosteal bone formation by basic fibroblast growth factor in rats. Growth Factors. 9:73-80.

20. Aspenberg, P., and L. S. Lohmander. 1989. Fibroblast growth factor stimulates bone formation. Acta Orthop. Scand. 60:473-476.

21. Akamine, T., W. S. S. Jee, H. Z. Ke, X. J. Li, and B. Y. Lin. 1992 Prostaglandin $E_{2}$ prevents bone loss and adds extra bone to immortalized diatal femoral methaphysics in female rats. Bone. 13:11-22.

22. Jee, W. S. S., K. Ueno, Y. P. Deng, and D. M. Woodbury. 1985. The effects of prostaglandine E2 in growing rats: increased metaphyseal hard tissue and corticoendosteal bone formation. Calcif. Tissue Int. 37:148-156.

23. Keller, J., A. Klamer, B. Bak, and P. Suder. 1993. Effects of local prostaglandin $\mathrm{E}_{2}$ on fracture callus in rabbits. Acta Orthop. Scand. 64:59-63.

24. Miller, S. C., and S. C. Marks. 1993. Local stimulation of new bone formation by prostaglandin $E_{1}$ : quantitative histomorphometry and comparison of delivery by minipumps and controlled-release pellets. Bone. 14:143-152.

25. Candela, M., S. C. Barker, and L. R. Ballou. 1993. Fibroblast growth factor increases TNF alpha receptor expression in human fibroblasts. Mol. Cell. Biochem. 120:43-50.

26. Goddard, D. H., S. L. Grossman, R. Newton, M. A. Clark, and J. S Bomalaski. 1992. Regulation of synovial cell growth: basic fibroblast growth factor synergizes with interleukin- $1 \beta$ stimulating phospholipase $A_{2}$ enzyme activity, phospholipase $A_{2}$ activating production and release of prostaglandin $E_{2}$ by rheumatoid arthritis synovial cells in culture. Cytokine. 4:377-384.

27. Tamura, K., R. Asakai, and R. Okamoto. 1991. Basic fibroblast growth factor in rat corpus luteum stimulates prostaglandin $F_{2 \alpha}$ production. Biochem Biophys. Res. Commun. 178:393-399.

28. Smith, W. L. 1992. Prostanoid biosynthesis and mechanisms of action Am. J. Physiol. 263:F181-F191.

29. Kujubu, D. A., B. S. Fletcher, B. C. Varnum, R. W. Lim, and H. R. Herschman. 1991. TIS10, a phorbol ester tumor promoter-inducible mRNA from Swiss 3T3 cells, encodes a novel prostaglandin synthase/cyclooxygenase homologue. J. Biol. Chem. 266:12866-12872.

30. O'Banion, M. K., H. B. Sadowski, V. Winn, and D. A. Young. 1991. A serum and glucocorticoid-regulated 4-kilobase mRNA encodes a cyclooxygenaserelated protein. J. Biol. Chem. 266:23261-23267.

31. Xie, W., J. G. Chipman, D. L. Robertson, R. L. Erikson, and D. L. 
Simmons. 1991. Expression of a mitogen-responsive gene encoding prostaglanding synthase is regulated by mRNA splicing. Proc. Natl. Acad. Sci. USA. 88:2692-2696.

32. Pilbeam, C. C., H. Kawaguchi, Y. Hakeda, O. S. Voznesensky, C. B. Alander, and L. G. Raisz. 1993. Differential regulation of inducible and constitutive prostaglandin endoperoxide synthase in osteoblastic MC3T3-E1 cells. J. Biol. Chem. 268:25643-25649.

33. Kawaguchi, H., L. G. Raisz, O. S. Voznesensky, C. B. Alander, Y. Hakeda, and C. C. Pilbeam. 1994. Regulations of the two prostaglandin G/H synthases by parathyroid hormone, interleukin-1, cortisol and prostaglandin $E_{2}$ in cultured neonatal mouse calvariae. Endocrinology 135:1157-1164.

34. Harrison, J. R., J. A. Lorenzo, H. Kawaguchi, L. G. Raisz, and C. C. Pilbeam. 1994. Stimulation of prostaglandin $\mathrm{E}_{2}$ production by interleukin- $1 \alpha$ and transforming growth factor $\alpha$ in osteoblastic MC3T3-E1 cells. J. Bone Miner. Res. 9:817-823.

35. Fletcher, B. S., D. A. Kujubu, D. M. Perrin, and H. R. Herschman. 1992. Structure of the mitogen-inducible TIS10 gene and demonstration that the TIS10encoded protein is a functional prostaglandin G/H synthase. J. Biol. Chem. 267:4338-4344.

36. Chomczynski, P., and N. Sacchi. 1987. Single-step method of RNA isolation by acid guanidinium thiocyanate-phenol-chloroform extraction. Anal. Biochem. 162:156-159.

37. Hill, D. L., M. Logan, D. Ong, D. DeSousa, and A. M. Gonzales. 1992 Basic fibroblast growth factor is synthesized and released by isolated ovine fetal growth plate chondrocytes: potential role as an autocrine mitogen. Growth Factors. 6:277-294.

38. L. G. Raisz, and H. A. Simmons. 1985. Effects of parathyroid hormone and cortisol on prostaglandin production by neonatal rat calvaria in vitro. Endocr. Res. 11:59-74.

39. Otto, J. C., D. L. DeWitt, and W. L. Smith. 1993. N-glycosylation of prostaglandin endoperoxide synthases- 1 and -2 and their orientations in the endoplasmic reticulum. J. Biol. Chem. 268:18234-18242.
40. O'Banion, M. K., V. D. Winn, and D. A. Young. 1992. cDNA cloning and functional activity of a glucocorticoid-regulated inflammatory cyclooxygenase. Proc. Natl. Acad. Sci. USA. 89:4888-4892.

41. Pilbeam, C. C., L. G. Raisz O. Voznesensky, C. B. Alander, B. N. Delman, and $H$. Kawaguchi. 1995. Autoregulation of inducible prostaglandin $G / H$ synthase by prostaglandins in osteoblastic cells. J. Bone Miner. Res. 10:406-414

42. Hurley, M. M., C. Abreu, J. R. Harrison, A. C. Lichtler, L. G. Raisz, and B. E. Kream. 1993. Basic fibroblast growth factor inhibits type I collagen gene expression in osteoblastic MC3T3-E1 cells. J. Biol. Chem. 268:5588-5593.

43. Hurley, M. M., C. Abreu, J. Lorenzo, A. Ray, and G. Gronowicz. 1994. Regulation of NF-IL6 and IL-6 expression by basic fibroblast growth factor in osteoblastic MC3T3-E1 cells. J. Bone Miner. Res. 9 (Suppl. 1):S164. (Abstr.)

44. Okazaki, R., K. Ikeda, A. Sakamoto, T. Nakano, K. Morimoto, T. Kikuchi, K. Urakawa, E. Ogata, and T. Matsumoto. 1992. Transcriptional activation of cfos and c-jun protooncogenes by serum growth factors in osteoblast-like MC3T3-

E1 cells. J. Bone Miner. Res. 7:1149-1154.

45. Xie, W., B. S. Fletcher, R. D. Anderson, and H. R. Herschman. 1994. vsrc induction of the TIS10PGS2 prostaglandin synthase gene is mediated by an ATF/CRE transcription response element. Mol. Cell. Biol. 14:6531-6539.

46. Hurley, M. M., M. Kessler, G. Gronowicz, and L. G. Raisz. 1992. The interaction of heparin and basic fibroblast growth factor on collagen synthesis in 21-day fetal rat calvariae. Endocrinology. 130:2675-2682.

47. Kawaguchi, H., C. C. Pilbeam, F. N. Woodiel, and L. G. Raisz. 1992. Comparison of the effects of 3,5,3-triiodothyroacetic acid and triiodothyronine on bone resorption in cultured fetal rat long bones and neonatal mouse calvariae. $J$. Bone Miner. Res. 9:247-253.

48. Raisz, L. G., R. A. Luben, G. R. Mundy, J. W. Dietrich, J. E. Horton, and C. L. Trummel. 1975. Effect of osteoclast activating factor from human leukocytes on bone metabolism. J. Clin. Invest. 56:408-413.

49. Gowen, M., D. D. Wood, E. J. Ihrie, M. K. B. McGuire, and R. G. G. Russell. 1983. An interleukin 1 like factor stimulates bone resorption in vitro. Nature (Lond.). 303(5941):378-380. 